\title{
Identifikasi Faktor Penyebab Kecelakaan Lalu Lintas Pada Ruas Jalan Luar Kota Banjarbaru
}

\author{
Utami Sylvia Lestari ${ }^{* 1}$, Annisa Khairat ${ }^{2}$ \\ ${ }^{1}$ Program Studi Teknik Sipil, Fakultas Teknik, Universitas Lambung Mangkurat \\ ${ }^{2}$ Mahasiswa Program Studi Teknik Sipil, Fakultas Teknik Universitas, Lambung Mangkurat \\ E-mail: *utami.s.lestari@ulm.ac.id
}

Received 28 February 2021; Reviewed 19 March 2021; Accepted 15 July 2021

Journal Homepage: http://jurnal.borneo.ac.id/index.php/borneoengineering

\begin{abstract}
The number of traffic accidents in South Kalimantan Province continues to increase, including in The City of Banjarbaru. The factors that cause traffic accidents are closely related to the constituent elements of traffic, namely road users, vehicles, roads, and the environment. The data collection technique for this study used a questionnaire, while the measurement scale in this study used the Likert scale. The data analysis stage was using the regression analysis test, namely, the logistic regression test using the SPSS (Statistical Product and Service Solution) Version 25 program by using the coefficient $(B)$ and the significance value of the results of the Variable in Equation. The results of the identification of the most dominant in each factor are caused by fatigue and drowsiness in human factors. The most dominating vehicle factor is damage to the traffic light system. Meanwhile, environmental factors are the animals roaming the streets. The dominant indicator is obtained from the results of logistic regression analysis in the variable table in the equation based on the coefficient value (B) for each factor.
\end{abstract}

Keywords: Traffic Accidents; Logistic Regression; SPSS

\begin{abstract}
Abstrak
Angka kecelakaan lalu lintas di Provinsi Kalimantan Selatan terus meningkat, termasuk di Kota Banjarbaru. Faktor-faktor penyebab terjadinya kecelakaan lalu lintas berkaitan erat dengan unsur-unsur pembentuk lalu lintas yaitu pemakai jalan, kendaraan, jalan, dan lingkungan. Teknik pengumpulan data untuk penelitian ini menggunakan kuesioner, sedangkan skala pengukuran dalam penelitian ini menggunakan Skala likert. Tahap analisis data dengan uji analisis regresi yaitu uji regresi logistik dengan alat bantu program SPSS (Statistical Product and Service Solution) Versi 25 dengan menggunakan angka koefisien (B) dan nilai signifikansi hasil Variabel in Equation. Hasil identifikasi yang paling dominan pada masing-masing faktor disebabkan oleh kelelahan dan mengantuk pada faktor manusia. Pada faktor kendaraan yang paling mendominasi adalah kerusakan pada sistem lampu lalu lintas. Sedangkan pada faktor lingkungan adalah binatang yang berkeliaran di jalan. Indikator dominan diperoleh dari hasil analisis regresi logistik dalam tabel variabel in equation berdasarkan besaran nilai koefisien (B) pada masing-masing faktor.
\end{abstract}

Kata kunci: Kecelakaan Lalu Lintas; Regresi Logistik; SPSS

\section{Pendahuluan}

Peningkatan jumlah penduduk memberikan sejumlah efek negatif dalam berbagai aspek. Salah satunya adalah peningkatan angka kecelakaan lalu lintas yang menjadi penyebab kematian terbesar yang disebabkan kejadian yang tidak disengaja (Syahriza, 2019). Jumlah penduduk yang mengalami 
peningkatan mengakibatkan terjadinya peningkatan kepemilikan kendaraan yang juga akan meningkatkan angka kecelakaan lalu lintas (Lestari \& Novianty, 2019). Kecelakaan lalu lintas adalah penyebab kematian nomor satu untuk anak-anak dan orang dewasa produktif di bawah umur 30 tahun (World Health Organization, 2018). Angka kematian yang semakin meningkat akibat kecelakaan lalu lintas juga akan menyebabkan kerugian dalam bidang ekonomi sehingga perlu menjadi issue penting dan menjadi prioritas bagi semua pihak untuk segera ditangani (Syahriza, 2019). Permasalahan fatalitas akibat kecelakaan lalu lintas harus segera diatasi melalui kerjasama seluruh pihak terkait baik pemerintah, kepolisian, akademisi, masyarakat umum ataupun pihak lainnya (Enggarsasi \& Sa'diyah, 2017).

Kecelakaan dapat ditafsirkan sebagai suatu peristiwa tidak diharapkan yang melibatkan paling sedikit satu kendaraan bermotor dan mengakibatkan kerugian material sampai menelan korban jiwa (UU RI No.22 Tahun 2009). Beberapa penelitian faktor yang menjadi menyebab kecelakaan lalu lintas sudah pernah dilakukan oleh beberapa peneliti. Di Kabupaten Malang, kecelakaan lalu lintas paling dominan disebabkan oleh faktor manusia (Marsaid et al., 2013). Di Kota Samarinda, faktor penyebab kecelakaan yang dominan untuk siswa SMA adalah perilaku yang melanggar peraturan pada saat berkendara (Setyowati et al., 2018). Sedangkan penelitian lainnya yang dilakukan di Kecamatan Banjarmasin Tengah Kota Banjarmasin didapatkan bahwa faktor dominan yang menjadi penyebab kecelakaan adalah faktor manusia, kendaraan dan jalan (Azizirrahman et al., 2015).

Kota Banjarbaru sebagai salah satu kota terbesar di Kalimantan Selatan tentunya memiliki berbagai macam aktivitas seperti kawasan perkantoran, kawasan perniagaan, kawasan pendidikan dan kawasan wisata. Peningkatan jumlah penduduk setiap tahunnya mengalami peningkatan yang cukup signifikan. Dengan adanya berbagai macam aktivitas tersebut akan menarik pergerakan kendaraan (lalu lintas) yang bergerak menuju dan dari kawasan tersebut sehingga ruas jalan menuju dan dari kota Banjarbaru sering menjadi tempat terjadinya kecelakaan lalu lintas, yang mengakibatkan angka kecelakaan berlalu lintas di Kota Banjarbaru juga ikut meningkat. Angka kematian akibat kecelakaan lau lintas yang terjadi di Kota Banjarbaru perlu ditekan supaya dapat berkurang. Untuk itu hal pertama yang pelu dilakukan adalah mengetahui faktor dominan penyebab kecelakaan yang terjadi melalui penelitian ini. Penelitian ini dilakukan dengan meminta pendapat masyarakat sebagai pengguna jalan untuk berpartisipasi dalam memberikan masukan terhadap faktor-faktor yang menyebabkan kecelakaan lalu lintas. Tujuan dilakukan penelitian ini adalah untuk mengidentifikasi dan menganalisis faktor-faktor yang menyebabkan kecelakaan lalu lintas di ruas jalan luar Kota Banjarbaru serta mengidentifikasi indikator yang dominan dari faktor-faktor tersebut.

\section{Metode Penelitian}

Teknik pengumpulan data untuk penelitian ini menggunakan kuesioner. Kuesioner merupakan teknik pengumpulan data yang dilakukan dengan memberi seperangkat pertanyaan atau pernyataan tertulis kepada responden untuk dijawab (Sugiyono, 2013). Tujuan utama dalam pembuatan kuesioner adalah untuk (a) memperoleh informasi yang relevan dengan tujuan survei, (b) memperoleh informasi dengan reliabilitas dan validitas setinggi mungkin (Singarimbun dan Effendi, 2006). Kuesioner tepat digunakan bila jumlah responden cukup besar dan tersebar di wilayah yang luas. Kuesioner berisi pertanyaan bersifat klarifikasi dan konfirmasi dengan mengunakan skala Likert, dimana setiap butir pertanyaan dibagi menjadi dua skala ukuran yaitu setuju dan tidak setuju. Skala ordinal digunakan untuk mengukur sikap, pendapat, dan persepsi seseorang atau sekelompok orang tentang fenomena sosial (Sugiono, 2017). Dengan terukurnya sikap, pendapat, dan persepsi, maka variabel yang dinilai dapat dijabarkan menjadi indikator variabel dimana responden dalam 
menentukan jawaban dengan mengikuti pertanyaan-pertanyaan yang sebelumnya telah disusun melalui item-item yang ditentukan. Jenis penelitian ini merupakan penelitian kuantitatif. Karena dalam penelitian ini menjelaskan fakta yang menentukkan beberapa faktor yang dapat mempengaruhi kecelakaan lalu lintas. Berdasarkan latar belakang dan rumusan masalah yang ada, karakteristik masalah yang diteliti dalam penelitian ini menjelaskan tentang menguji beberapa variabel melalui pengujian hipotesis.

Pengambilan data untuk penelitian ini dilakukan kepada para pengguna jalan di ruas Jalan A Yani Km 33 - 63 yaitu ruas jalan Banjarbaru menuju Pelaihari yang termasuk dalam Jalan Nasional dengan nomor ruas 005. Suatu studi transportasi disarankan mempunyai ukuran sampel antara 300 sampai dengan 400 responden (Pearmin et al., 1991). Sehingga dalam penelitian ini ditentukan jumlah sampel sebanyak 300 sampel yaitu responden yang memiliki Surat Ijin Mengemudi (SIM). Pemilihan responden penelitian dipertimbangkan berdasarkan pengetahuan dan pemahaman yang dimiliki responden terhadap kecelakana lalu lintas di luar kota Banjarbaru yang dimaksudkan agar dapat memberikan jawaban kuisioner yang benar dan mencerminkan pendapat yang sebenarbenarnya dari responden yang bersangkutan terhadap dimensi dan indikator variabel penelitian.

Analisis data yang dilakukan menggunakan regresi logistik, merupakan salah satu model regresi yang dapat menjelaskan hubungan antara variabel respon yang bersifat kategorik dikotomus (berskala nominal atau ordinal terdiri dari dua kategori) dan polikotomus (berskala nominal atau ordinal lebih dari dua kategori) dengan satu atau lebih variabel prediktor yang bersifat kategorik dan atau kontinu. Dan dibantu dengan uji kesesuaian model, yang dilakukan untuk mengetahui apakah ada perbedaan antara hasil observasi dengan kemungkinan hasil prediksi model. Teknik analisis dalam mengolah data ini tidak memerlukan uji normalitas dan uji asumsi klasik pada variabel independennya (Ghozali, 2011).

Faktor-faktor penyebab terjadinya kecelakaan berkaitan dengan unsur-unsur pembentuk lalu lintas yaitu pengguna jalan (pengemudi), kendaraan, jalan, dan lingkungan. Faktor-faktor tersebut kemudian dibagi menjadi beberapa indikator (Kadiyali, 1973), (Narang \& Radam, 2019). Salah satu analisis yang bisa digunakan untuk menentukan faktor yang menjadi penyebab kecelakaan adalah dengan menggunakan regresi logistik (Sari \& Radam, 2019). Data primer yang digunakan sebagai variabel penelitian terdiri atas variabel tidak bebas (dependen) dan variabel bebas (independen). Adapun yang termasuk variabel tidak bebas dan variabel-variabel bebas yang dijadikan acuan sebagai data primer penelitian ini diantaranya (Narang \& Radam, 2019):

a. Variabel respon / tidak bebas (Y) adalah kecelakaan lalu lintas dengan kategori:

$0=$ Tidak Terjadi Kecelakaan Lalu Lintas

$1=$ Terjadi Kecelakaan Lalu Lintas

b. Variabel-variabel bebas $\left(\mathrm{X}_{\mathrm{i}}\right)$ yang diduga mempengaruhi terjadinya kecelakaan lalu lintas yaitu:

- Faktor Manusia/Pengemudi $\left(\mathrm{X}_{1}-\mathrm{X}_{6}\right)$

- Faktor Kendaraan $\left(\mathrm{X}_{7}-\mathrm{X}_{12}\right)$

- Faktor Jalan $\left(\mathrm{X}_{13}-\mathrm{X}_{18}\right)$

- Faktor Lingkungan $\left(\mathrm{X}_{19}-\mathrm{X}_{22}\right)$

Langkah pertama yang dilakukan dalam analisis regresi logistik adalah menilai kelayakan model regresi. Syarat nilai signifikansi yang ditunjukkan uji ini adalah harus lebih besar 5\% atau lebih dari 0,05 sehingga goodness of fit model baik dan model regresi untuk uji tes ini dapat diterima. Tahap selanjutnya dalam analisis regresi logistik adalah menilai keseluruhan model regresi (overall model fit) dan uji koefisien determinan. Adapun kriteria uji kesesuaian model dapat dilihat dari beberapa pengujian diantaranya pengujian Hosmer Lemeshow, Omnibus Test of Model Coefficients dan Negalgarke R-Square (Hayati, 2014). Hasil analisis penelitian ini adalah didapatkannya faktor yang mempengaruhi terjadinya kecelakaan lalu lintas. 
Adapun diagram alir penelitian dapat dilihat pada gambar 1 berikut ini,

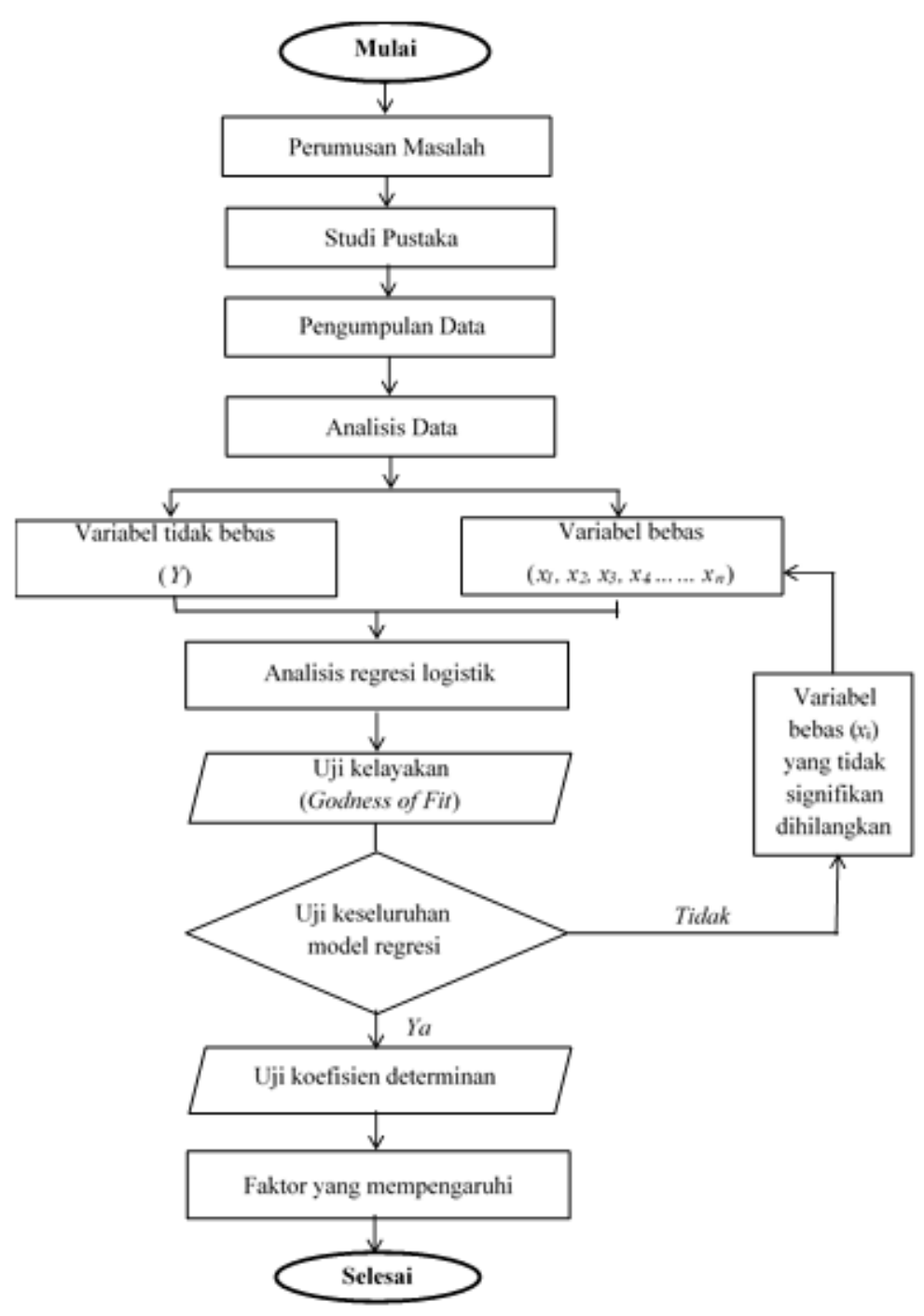

Gambar 1. Diagram alir penelitian

\section{Hasil dan Pembahasan}

\subsection{Analisis Data Penelitian}

\subsubsection{Analisis Regresi Logistik (Model 1)}

1. Menilai Goodness of Fit Model Penelitian

Langkah pertama yang dilakukan dalam analisis regresi logistik adalah menilai kelayakan model regresi. Untuk menilai kelayakan model regresi (Goodness of fit) yakni dengan Hosmer and Lemeshow Test. Adapun hasil Hosmer and Lemeshow Test digambarkan dalam tabel 1.

Tabel 1. Goodness of Fit (Model 1)

\begin{tabular}{cccc}
\hline Step & Chi-square & df & Sig. \\
\hline 1 & .000 & 8 & 1.000
\end{tabular}

Sumber: Hasil Analisa, 2021 
Tabel 1 menunjukkan bahwa nilai signifikansi adalah 1,000. Nilai signifikansi yang ditunjukkan dalam tabel tersebut adalah lebih besar 5\% atau lebih dari 0,05 sehingga goodness of fit model baik dan model regresi untuk uji tes ini dapat diterima.

2. Menilai Overall Model Keseluruhan Model

Tahap selanjutnya dalam analisis regresi logistik adalah menilai Keseluruhan Model regresi (overall model fit). Untuk menilai Keseluruhan Model regresi yakni dengan memperhatikan nilai $-2 \log$ likelihood block number $=0$ dan block number $=1$. Adapun nilai $-2 \log$ likelihood block number $=0$ dan block number $=1$ disajikan dalam tabel 2.

Tabel 2. Overall Model Fit (Model 1)

\begin{tabular}{rc}
\hline Iteration History & $\mathbf{- 2 ~ L o g ~ L i k e l i h o o d ~}$ \\
\hline Step 0 & 831,777 \\
Step 1 & 186,772 \\
\hline
\end{tabular}

Sumber: Hasil Analisis, 2021

Mengacu pada Tabel 2 nilai -2log likelihood pada block number $=0$ adalah 831,777sedangkan nilai -2log likelihood pada block number $=1$ adalah 186,772. Dengan demikian, model regresi secara keseluruhan layak karena terjadi penurunan nilai -2log likelihood pada block number 1.

3. Menilai Omnibus Tests of Model Coefficients Model

Adapun omnibus test sof model coefficients dalam analisis regresi logistik bertujuan untuk mengetahui apakah semua variabel bebas atau salah satu satu variabel bebas berpengaruh terhadap variabel dependen. Hasil omnibus tests of model coefficients ditunjukkan oleh tabel 3.

Tabel 3. Omnibus Tests of Model (Model 1)

\begin{tabular}{ccccc}
\hline & & Chi-square & Df & Sig. \\
\hline Step 1 & Step & 831,777 & 22 & .000 \\
& Block & 831,777 & 22 & .000 \\
Model & 831,777 & 22 & .000 \\
\hline Sumber: Hasil Analisis, 2021 & & &
\end{tabular}

Tabel 3 menunjukkan bahwa nilai signifikansi model adalah 0,000 yang menunjukan bahwa tingkat signifikansi berada di bawah 5\% atau 0,05 yang berarti variabel bebas yang digunakan pada penelitian ini secara bersama-sama berpengaruh terhadap kecelakaan lalu lintas pada ruas jalan luar kota Banjarbaru.

4. Menilai Koefisien Determinan Penelitian

Penilaian koefisien determinan penelitian dilakukan dengan uji Cox dan Snell RSquare serta Nagelkerke RSquare adalah untuk mengetahui kofisien determinan dari faktorfaktor yang digunakan dalam penelitian sebagai variabel independen terhadap terjadinya kecelakaan di ruas jalan luar kota Banjarbaru dapat dilihat pada tabel 4.

Tabel 4. Cox \&Snell R Square dan Nagelkerke R Square (Model 1)

\begin{tabular}{|c|c|c|}
\hline No. & Deskripsi & Value \\
\hline 1. & Cox \& Snell R-Square & 0,750 \\
\hline 2. & Nagelkerke R-Square & 1,000 \\
\hline
\end{tabular}

Sumber: Hasil Analisis, 2021 
Berdasarkan tabel 4, nilai Cox \& Snell R-Square sebesar 0,750 menunjukkan bahwa faktor-faktor sebagai variabel independent yang dikemukakan dalam penelitian ini memiliki keterkaitan yang erat dengan penyebab terjadinya kecelakaan lalu lintas pada ruas jalan luar kota Banjarbaru, yaitu sebesar 75,0\%. Sedangkan nilai Nagelkerke RSquare sebesar 1,000 menunjukkan bahwa seluruh faktor-faktor sebagai variabel independen pada penelitian ini berpengaruh sebesar $100 \%$.

5. Analisis Pengaruh Faktor penelitian

Hasil pengujian pengaruh kelelahan dan mengantuk, berkendara dengan kecepatan tinggi, kurangnya konsentrasi akibat faktor internal, kurangnya konsentrasi akibat faktor eksternal, kurang disiplin, kurang keahlian dalam mengemudi, kegagalan fungsi rem, gangguan ban, kelebihan muatan, kerusakan sistem lampu, kerusakan system kemudi, ketidaklengkapan bagian kendaraan, kondisi perkerasan, kondisi tikungan, jalan licin disaat hujan, penerangan jalan umum, permukaan jalan beerbatu licin akibat oli atau minyak, perlengkapan jalan, cuaca/ iklim, binatang berkeliaan dijalan, hambaan samping, dan kepadatan lingkungan terhadap terjadinya kecelakaan lalu lintas berdasarkan asumsi responden adalah dengan menganalisis hasil variable in the equation, seperti pada tabel 5.

Tabel 5. Hasil Pengujian Pengaruh Faktor Penyebab Kecelakaan Lalu Lintas pada Ruas Jalan Luar Kota Banjarbaru (Model 1)

\begin{tabular}{|c|c|c|c|c|c|c|}
\hline $\begin{array}{l}\text { Faktor } \\
\text { Pengaruh }\end{array}$ & & Indikator & Koefisien & $\begin{array}{l}\operatorname{Exp} \\
(\mathbf{B})\end{array}$ & Sig. & Keterangan \\
\hline \multirow{6}{*}{$\begin{array}{l}\text { Faktor Manusia } \\
\text { (Pengemudi) }\end{array}$} & X1. & Kelelahan dan mengantuk & 10.475 & 35406 & 996 & Tidak \\
\hline & X2. & $\begin{array}{l}\text { Berkendara dengan } \\
\text { kecepatan tinggi }\end{array}$ & -2.912 & .054 & 999 & Tidak \\
\hline & X3. & $\begin{array}{l}\text { Kurangnya konsentrasi } \\
\text { akibat faktor internal }\end{array}$ & -1.580 & 206 & 1.000 & Tidak \\
\hline & X4. & $\begin{array}{l}\text { Kurangnya konsentrasi } \\
\text { akibat faktor eksternal }\end{array}$ & -2.109 & 121 & 1.000 & Tidak \\
\hline & X5. & Kurang disiplin & 8.654 & 5732 & .997 & Tidak \\
\hline & X6. & $\begin{array}{l}\text { Kurang keahlian dalam } \\
\text { mengemudi }\end{array}$ & 2.762 & 15.838 & 999 & Tidak \\
\hline \multirow{6}{*}{$\begin{array}{l}\text { Faktor } \\
\text { Kendaraan }\end{array}$} & X7. & Kegagalan fungsi rem & 1.202 & 3.328 & 1.000 & Tidak \\
\hline & X8. & Gangguan ban & 2.769 & 15.950 & .999 & Tidak \\
\hline & X9. & Kelebihan muatan & -.081 & 922 & 1.000 & Tidak \\
\hline & X10. & Kerusakan sistem lampu & 5.080 & 160.83 & 999 & Tidak \\
\hline & X11. & Kerusakan system kemudi & .722 & 2.060 & 1.000 & Tidak \\
\hline & X12. & $\begin{array}{l}\text { Ketidaklengkapan bagian } \\
\text { kendaraan }\end{array}$ & 1.427 & 4.164 & 1.000 & Tidak \\
\hline \multirow[t]{6}{*}{ Faktor Jalan } & X13. & Kondisi perkerasan & 3.045 & 21.005 & 1.000 & Tidak \\
\hline & X14. & Kondisi tikungan & -4.885 & .008 & .998 & Tidak \\
\hline & X15. & Jalan licin disaat hujan & -1.994 & .136 & 999 & Tidak \\
\hline & X16. & Penerangan jalan umum & -2.245 & .106 & .999 & Tidak \\
\hline & X17. & $\begin{array}{l}\text { Permukaan jalan beerbatu, } \\
\text { licin akibat oli atau minyak }\end{array}$ & -.880 & 415 & 1.000 & Tidak \\
\hline & X18. & Perlengkapan jalan & .376 & 1.457 & 1.000 & Tidak \\
\hline Faktor & X19. & Cuaca/ iklim & 1.492 & 4.445 & 1.000 & Tidak \\
\hline \multirow[t]{3}{*}{ Lingkungan } & X20. & Binatang berkeliaan dijalan & 4.762 & 116.93 & 999 & Tidak \\
\hline & X21. & Hambaan samping & 5.565 & 261.09 & 999 & Tidak \\
\hline & X22. & $\begin{array}{l}\text { Kepadatan lingkungan } \\
\text { Konstanta }\end{array}$ & $\begin{array}{l}2.206 \\
-115.319\end{array}$ & 9.082 & 999 & Tidak \\
\hline
\end{tabular}

Sumber: Hasil Analisis, 2021 
Berdasarkan Tabel 5 hasil uji variabel in equation tersebut, maka persamaan regresi logistik dapat disusun sebagai berikut.

$$
\begin{gathered}
\operatorname{Ln} \frac{p}{1-p}=-115.319-2,912_{\text {kelelahan }}-1,580_{\text {kecepatan tinggi }}-2,109_{\text {faktor internal }}+8,654_{\text {faktor eksternal }}+ \\
2,762_{\text {kurang disiplin }}+1,202_{\text {kurang keahlian }}+2,769_{\text {kegagalan rem }}+1,202_{\text {gangguan ban }}-0,081_{\text {kelebihan muatan }}+ \\
\text { 5,080 } \text { kerusakan lampu }+0,722_{\text {kerusakan kemudi }}+1,427_{\text {ketidaklenggkapan part }}+3,045_{\text {kondisi perkerasan }}- \\
\text { 4,885 kondisi tikungan }-1,994_{\text {jalan licin }}-2,245_{\mathrm{PJU}}-0,880_{\text {permukaan jalan }}+0,376_{\text {Perlengkapan jalan }}+ \\
\text { 1,492 } 2_{\text {cuaca }}+4,762_{\text {binatang liar }}-5,565_{\text {hambatan samping }}+2,206_{\text {Kepadatan lingkunggan }}
\end{gathered}
$$

Dari analisis tersebut didapatkan nilai signifikan adalah sebesar 0,000 dimana nilai tersebut lebih kecil dari nilai $\alpha(0,05)$ sehingga dapat dinyatakan bahwa hasil penelitian menunjukkan bahwa seluruh variabel penelitian pada uji model 1 ini tidak berpengaruh secara signifikan terhadap terjadinya kecelakaan lalu lintas di ruas jalan luar kota, yang berarti hasil tersebut tidak memenuhi syarat yang telah ditentukan.

\subsubsection{Analisis Regresi Logistik (Model 2)}

Berdasarkan hasil uji regresi logistik pada model 1, maka dilakukan analisis regresi logistik model 2 dengan melakukan kombinasi antara variabel bebas yang berpengaruh, dengan melihat nilai korelasi dari variabel bebas pada model 1, dan dengan menggunakan metode trial and error. Variabel yang diuji adalah variabel yang mempunyai nilai korelasi antar variabel yang rendah, sehingga dari analisis tersebut didapat variabel-variabel bebas yang berpengaruh dan memenuhi syarat untuk suatu persamaan. Adapun hasil analisis yang dihasilkan dari pengembangan model 2 untuk mengetahui tingkat signifikan dari faktor-faktor penelitian, adalah sebagai berikut:

1. Menilai Goodness of Fit Model Penelitian

Untuk menilai kelayakan model regresi (Goodness of fit) yakni dengan Hosmer and Lemeshow Test. Adapun hasil Hosmer and Lemeshow Test digambarkan dalam tabel 6.

Tabel 6. Goodness of Fit (Model 2)

\begin{tabular}{cccc}
\hline Step & Chi-square & df & Sig. \\
\hline 1 & 0,092 & 7 & 1.000 \\
\hline
\end{tabular}

Tabel 6 menunjukkan bahwa nilai signifikansi adalah 0,328. Nilai signifikansi yang ditunjukkan dalam tabel tersebut adalah lebih besar 5\% atau lebih dari 0,05 sehingga goodness of fit model baik dan model regresi untuk uji tes ini dapat diterima.

2. Menilai Overall Model Keseluruhan Model

Tahap selanjutnya dalam analisis regresi logistik adalah menilai Keseluruhan Model regresi (overall model fit). Untuk menilai Keseluruhan Model regresi yakni dengan memperhatikan nilai -2log likelihood block number $=0$ dan block number=1. Adapun nilai -2log likelihood block number=0 dan block number=1 disajikan dalam tabel 7.

Tabel 7. Overall Model Fit (Model 2)

\begin{tabular}{cc}
\hline Iteration History & -2 Log Likelihood \\
\hline Step 0 & 831,777 \\
Step 1 & 234,254 \\
\hline
\end{tabular}

Sumber: Hasil Analisis, 2021

Mengacu pada tabel 7, nilai -2log likelihood pada block number $=0$ adalah 831,777 sedangkan 
nilai -2log likelihood pada block number $=1$ adalah 234,254. Dengan demikian, model regresi secara keseluruhan layak karena terjadi penurunan nilai -2log likelihood pada block number 1.

3. Menilai Omnibus Tests of Model Coefficients Model

Adapun omnibus test sof model coefficients dalam analisis regresi logistik bertujuan untuk mengetahui apakah semua variabel bebas atau salah satu satu variabel bebas berpengaruh terhadap variabel dependen. Hasil omnibus tests of model coefficients pada model 2 ditunjukkan oleh tabel 8.

Tabel 8. Omnibus Tests of Model (Model 2)

\begin{tabular}{ccccc}
\hline & & Chi-square & Df & Sig. \\
\hline Step 1 & Step & 813,705 & 11 & .000 \\
& Block & 813,705 & 11 & .000 \\
& Model & 813,705 & 11 & .000 \\
\hline
\end{tabular}

Sumber: Hasil Analisis, 2021

Tabel 8 menunjukkan bahwa nilai signifikansi model adalah 0,000 yang menunjukkan bahwa tingkat signifikansi berada di bawah 5\% atau 0,05 yang berarti variabel bebas yang digunakan pada penelitian ini secara bersama-sama berpengaruh terhadap kecelakaan lalu lintas pada ruas jalan luar kota Banjarbaru.

4. Menilai Koefisien Determinan Penelitian

Penilaian koefisien determinan penelitian dilakukan dengan uji Cox dan Snell RSquare serta Nagelkerke RSquare yang hasilnya dapat dilihat pada tabel 9.

Tabel 9. Cox \&Snell R Square dan Nagelkerke R Square (Model 2)

\begin{tabular}{ccc}
\hline No. & Deskripsi & Value \\
\hline 1. & Cox \& Snell $R$-Square & 0,742 \\
2. & Nagelkerke R-Square & 0,990 \\
\hline
\end{tabular}

Sumber: Hasil Analisis, 2021

Berdasarkan Tabel 9, nilai Cox \& Snell R-Square sebesar 0,742 menunjukkan bahwa faktor-faktor sebagai variabel independent memiliki keterkaitan yang erat dengan penyebab terjadinya kecelakaan lalu lintas pada ruas jalan luar kota Banjarbaru, yaitu sebesar 74,2\%. Sedangkan nilai Nagelkerke RSquare sebesar 0,990 menunjukkan bahwa seluruh faktor-faktor sebagai variabel independen berpengaruh sebesar 99,0\% dan selebihnya sebesar 1,0\% dipengaruhi oleh faktorfaktor lain yang tidak dikemukakan dalam penelitian ini.

5. Analisis Pengaruh Faktor penelitian

Hasil pengujian pengaruh berkendara dengan kecepatan tinggi, kurang disiplin, kegagalan fungsi rem, dan kelebihan muatan terhadap terjadinya kecelakaan lalu lintas berdasarkan asumsi responden adalah dengan menganalisis hasil variable in the equation, seperti pada tabel 10 .

Berdasarkan Tabel 10 hasil uji variabel in equation tersebut, maka persamaan regresi logistik dapat disusun sebagai berikut.

$\operatorname{Ln} \frac{p}{1-p}=-33.573 \alpha+2,674_{\text {kecepatan tinggi }}+3,163_{\text {kurang disiplin }}+2,164_{\text {kegagalan rem }}+2,543_{\text {kelebihan muatan }}$ 
Tabel 10. Hasil Pengujian Pengaruh Faktor Penyebab Kecelakaan Lalu Lintas pada Ruas Jalan Luar Kota Banjarbaru (Model 2)

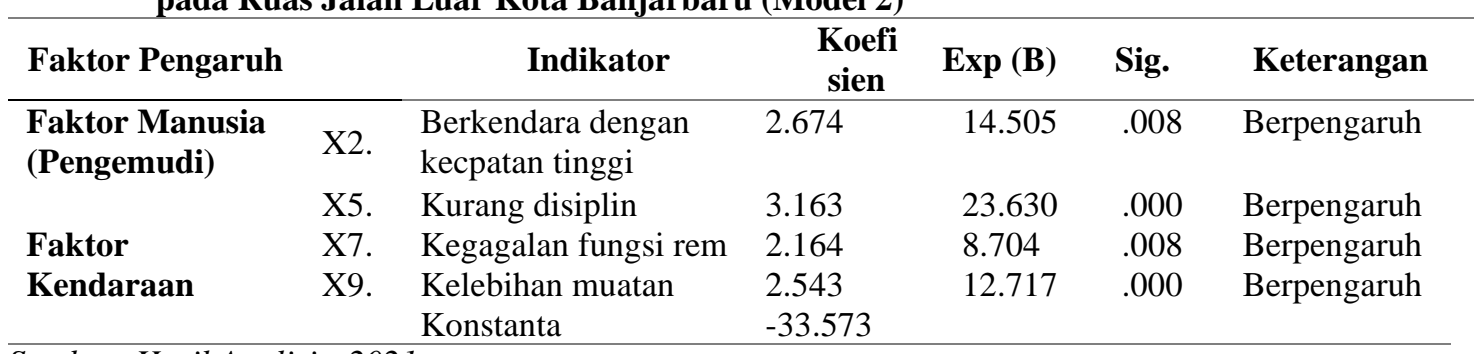

Sumber: Hasil Analisis, 2021

Deskripsi hasil:

a. Nilai konstanta sebesar $-33,573$ menunjukkan bahwa apabila seluruh faktor penelitian dalam variabel independen tidak mengalami perubahan (tidak terjadi peningkatan maupun penurunan) maka nilai terjadinya kecelakaan lalu lintas berdasarkan asumsi jawaban responden terhadap pertanyaan penelitian adalah sebesar 33,573 (nilai minus pada koefisien tidak dicantumkan karena nilai $\alpha$ merupakan koefisien yang berpindah ke ruas kiri dan menjadi plus).

b. Nilai koefisien $\mathrm{X}_{2}$ sebesar 2,674 menunjukkan bahwa peningkatan pada faktor kecepatan berkendaraan akan berdampak pada peningkatan kemungkinan terjadinya kecelakaan lalu lintas pada ruas jalan sebesar $267,4 \%$.

c. Nilai koefisien $\mathrm{X}_{5}$ sebesar 3.163 menunjukkan bahwa peningkatan pada faktor kurang disiplin akan berdampak pada peningkatan kemungkinan terjadinya kecelakaan lalu lintas pada ruas jalan sebesar 316,3\%.

d. Nilai koefisien $\mathrm{X}_{7}$ sebesar 1,040 menunjukkan bahwa apabila terjadi kegagalan fungsi rem kendaraan akan berdampak pada peningkatan kemungkinan terjadinya kecelakaan lalu lintas pada ruas jalan sebesar $104 \%$.

e. Nilai koefisien $X_{9}$ sebesar 2,543 menunjukkan bahwa peningkatan muatan kendaraan atau kendaraan mengalami overload akan berdampak pada peningkatan kemungkinan terjadinya kecelakaan lalu lintas sebesar $254,3 \%$

\subsection{Pembahasan Penelitian}

Dari hasil analisis menggunakan metode regresi logistik dengan program SPSS versi 25 diperoleh indikator-indikator yang berpengaruh terhadap terjadinya kecelakaan lalu lintas seperti dalam Tabel 11.

Tabel 11. Indikator yang Mempengaruhi Faktor Kecelakaan Lalu Lintas Pada Ruas Jalan Luar Kota Banjarbaru

\begin{tabular}{llc}
\hline \multicolumn{1}{c}{ Faktor pengaruh } & \multicolumn{1}{c}{ Indikator } & Kode \\
Faktor Manusia & Berkendara dengan kecepatan tinggi & $\mathrm{X}_{2}$ \\
(pengemudi) & Kurang disiplin & $\mathrm{X}_{5}$ \\
Faktor Kendaraan & Kegagalan fungsi rem & $\mathrm{X}_{7}$ \\
& Kelebihan muatan $($ Overload $)$ & $\mathrm{X}_{9}$ \\
\hline
\end{tabular}

Sumber: Hasil Analisis, 2021

\subsubsection{Kecelakaan Lalu Lintas yang Dipengaruhi oleh Faktor Manusia/ Pengemudi}

Faktor Manusia yang berpengaruh pada Kecelakaan Lalu Lintas di ruas jalan luar kota Banjarbaru dapat dijelaskan sebagai berikut:

1. Mengemudi dengan kecepatan $\left(\mathrm{X}_{2}\right)$

Mengemudi dengan kecepatan berlebihan (melebihi batas kecepatan) atau dengan kecepatan yang tidak tepat (mengemudi terlalu cepat untuk kondisi saat itu, tetapi tidak melebihi batas kecepatan

2. Kurang Disiplin $\left(\mathrm{X}_{5}\right)$ 
Kurang disiplin merupakan suatu bentuk keengganan seorang pengemudi untuk mematuhi peraturan yang telah ditetapkan. Perilaku kurang disiplin diantaranya menerobos lampu lalu lintas, sengaja melanggar rambu lalu lintas dan belum memiliki SIM serta bentuk ketidak disiplinan berkendara lainnya.

\subsubsection{Kecelakaan Lalu Lintas yang Dipengaruhi Oleh Faktor Kendaraan}

Fakta ini menyatakan bahwa Faktor Kendaraan sangat dominan menyebabkan terjadinya kecelakaan di ruas jalan luar kota Banjarbaru dapat dijelaskan sebagai berikut:

1. Gangguan Sistem Rem $\left(\mathrm{X}_{7}\right)$

Gangguan sistem rem adalah suatu keadaan dimana sistem perlambatan kendaraan tidak berkerja sebagaimana mestinya atau tidak mampu memperlambat/menghentikan laju kendaraan, diantaranya rem blong, rem lengket, rem kurang pakem (titik henti terlalu jauh).

2. Kelebihan Muatan (Overload) $\left(\mathrm{X}_{9}\right)$

Overload adalah suatu kondisi dimana kendaraan mengakomodir beban yang melebihi standar yang telah ditentukan pabrikasi dan cenderung pada ketidakmampuan mengakomodasi beban yang dibawanya.

\section{Kesimpulan}

Berdasarkan analisis faktor penyebab kecelakaan lalu lintas pada ruas jalan luar kota Banjarbaru diperoleh 4 indikator yang berpotensial mempengaruhi tingkat kecelakaan lalu lintas di ruas jalan luar kota Banjarbaru. Terdapat dua indikator yang disebabkan dari faktor manusia atau pengemudi, yaitu berkendara dengan kecepatan tinggi, serta kurang disiplin. Dari faktor kendaraan terdapat dua indikator yang berpotensial mengakibatkan kecelakaan lalu lintas, yaitu kegagalan fungsi rem, dan kelebihan muatan (overload). Sedangkan pada faktor jalan dan lingkungan tidak terdapat indikator potensial yang mengakibatkan kecelakaan lalu lintas di ruas jalan luar kota Banjarbaru. Untuk memperoleh indikator yang paling dominan pada masing-masing faktor ditentukan dengan besaran koefisien (B) tertinggi. Kecelakaan lalu lintas yang disebabkan berkendara dengan kecepatan tinggi menjadi indikator paling dominan pada faktor manusia. Pada faktor kendaraan ada dua indikator yang berpotensi menyebabkan kecelakaan lalu lintas namun kelebihan muatan yang lebih mendominasi. Indikator dominan diperoleh dari hasil analisis regresi logisik dalam tabel variabel in equation berdasarkan besaran nilai koefisien (B) pada masing-masing faktor.

\section{Daftar Pustaka}

Azizirrahman, M., Normelani, E., \& Arisanty, D., 2015, Faktor Penyebab Terjadinya Kecelakaan Lalu Lintas pada Daerah Rawan Kecelakaan di Kecamatan Banjarmasin Tengah Kota Banjarmasin, Jurnal Pendidikan Geografi, 2(3), 20-37.

Enggarsasi, U., \& Sa'diyah, N. K., 2017, Kajian Terhadap Faktor-Faktor Penyebab Kecelakaan Lalu Lintas Dalam Upaya Perbaikan Pencegahan Kecelakaan Lalu Lintas, Perspektif, 22(3), 228.

Ghozali, Imam, 2011, Aplikasi Analisis Multivariate Dengan Program SPSS, Semarang, Badan Penerbit Universitas Diponegoro.

Hayati, Erna, 2014, Analisis Regresi Logistik untuk Mengetahui Faktor-Faktor yang Mempengaruhi Frekuensi Kedatangan Pelanggan di Pusat Perbelanjaan "X”, Jurnal Ekbis, 12(3), 1-18.

Marsaid, Hidayat, M., \& Ahsan, 2013, Faktor Yang Berhubungan Dengan Kejadian Kecelakaan Lalu Lintas pada Pengendara Sepeda Motor di Wilayah Polres Kabupaten Malang, Jurnal Ilmu Keperawatan, 1(2), 98-112. 
Narang, R. I., \& Radam, I. F., 2019, The analysis of The Causative Factors of Traffic Accidents Rural Roads in Buntok, Global Journal of Engineering Science and Researches, 6(October), 21-29.

Kadiyali, 1973, Traffic Engineering and Transportation Planning, Khanna Pub.

Sari, N., \& Radam, I. F. ,2019, Factors Affecting the Willingness of Using Parking Area in Shopping Area in Banjarmasin, 04(02), 529-536.

Republik Indonesia, Undang-Undang Nomor 22 Tahun 2009 Tentang Lalu Lintas dan Angkutan Jalan, Lembaran Negara Republik Indonesia Nomor 96 Tahun 2009, Tambahan Lembaran Negara Republik Indonesia Nomor 5025.

Lestari, U. S., \& Novianty, N., 2019, Analisis Penanganan Daerah Rawan Kecelakaan di Ruas Jalan Ahmad Yani Kabupaten Tapin (Km 82-Km 114), Prosiding Forum Studi Transportasi Antar Perguruan Tinggi Ke-21, 19-20.

Setyowati, D. L., Firdaus, A. R., \& Rohmah, N., 2018, Factor Cause of Road Accidents at Senior High School Students in Samarinda, The Indonesian Journal of Occupational Safety and Health, 7(March), 329-338.

Sugiyono, 2013, Metode Penelitian Pendidikan Pendekatan Kuantitatif, Kualitatif, dan R\&D, Bandung, CV. Alfabeta.

Sugiyono, 2017, Metode Penelitian Kuantitatif, Kualitatif, dan R\&D, Bandung, CV. Alfabeta.

Syahriza, M., 2019, Kecelakaan Lalulintas : Perlukah Mendapatkan Perhatian Khusus?, Averrous: Jurnal Kedokteran Dan Kesehatan Malikussaleh, 5(2), 89.

Pearmain, D., Swanson, J., Bradley, M. \& Kroes, E., 1991, Stated Preference Techniques: A Guide to Practice (2nd edn), Rotterdam, Netherlands: Steer Davies Gleave and Hague Consulting Group.

World Health Organization, 2018, Global Status Report On Road Safety 2018, World Health Organization, Vol. 151 Issue 2. 
